\title{
Housing AFFordabiLITY: RECOMMENDATIONS FOR NEW Research to Guide Policy
}

\author{
Jane Dokko
}

\section{OVERVIEW \\ - In considering whether and how to address the problem of housing affordability, policy- makers seeking to base their decisions on empirical evidence will face gaps in the existing research. This article highlights key areas where new research could guide decision making.}

- Policymakers must agree on a rationale for acting, such as market efficiency or redistribution. To inform this discussion, new research is needed on the effectiveness of existing policies and the impact of regulation and flat incomes on affordability.

- Studies that assess whether the benefits of proposed policies outweigh the political costs would also be helpful, reducing policymakers' uncertainty about whether to proceed. In addition, new research could bolster policies that differ from those favored by self-interested stakeholders, whose views tend to prevail otherwise.

- Analyses of the relationship between secondary markets and housing costs could help policymakers decide whether to use housing finance reform to achieve affordability goals.
$\mathrm{M}$ any housing market analysts point to the financial burdens of high home prices and rents as justifying government intervention in housing markets. Indeed, in recent years, the cost burdens and presumed shortage of affordable housing have been recurring themes in numerous reports, news articles, policy debates, conferences, and market commentaries (see, for example, Gabriel and Painter [2017] and the Joint Center for Housing Studies [2018]). Prominently featured in these discussions are calls for new regulations, additional public resources, or the redesign of existing policies to reduce the cost of housing and increase the supply of affordable housing.

In this article, I discuss five issues that federal policymakers will likely grapple with if they are interested in promulgating evidence-based policy to address today's housing affordability challenges. I focus on areas where economic research is necessary to reduce the uncertainty in federal policy design choices, but also where there are gaps in the research. A goal of this discussion is to motivate pragmatic future research based on the questions that I anticipate would arise in a rational policymaking process on housing affordability at the federal level. New research on housing affordability would strengthen the evidence base on effective

\footnotetext{
Jane Dokko is an assistant vice president at the Federal Reserve Bank of Chicago. Email: jane.dokko@chi.frb.org.

The views expressed in this article are those of the author and do not necessarily reflect the position of the Federal Reserve Banks of Chicago or New York, or the Federal Reserve System. To view the author's disclosure statement, visit https://www.newyorkfed.org/research/epr/2018/epr_2018_housing-affordability_dokko.
} 
policy interventions, help policymakers evaluate risks and uncertainties, and make salient the trade-offs between different policy objectives.

\section{IDENTIFying A RATIONALE FOR GOVERNMENT INTERVENTION}

Rising home prices and rents, and their associated cost burdens, oversimplify the rationale for intervening in housing markets to improve affordability. After all, an undesirable price that is "too high" is rarely a sine qua non for government intervention in other markets. So why should policymakers intervene to address housing affordability? For one, a large literature analyzes the myriad housing market failures, including those stemming from externalities and asymmetric information. For example, recent research points to the role of high housing costs in holding back the agglomeration benefits of highly skilled workers locating near each other (Hsieh and Moretti 2017). And the mortgage market is a classic example of credit rationing in the presence of asymmetric information (Stiglitz and Weiss 1981).

In addition to efficiency-related reasons, policymakers may seek to use housing policy to redistribute income and wealth. Indeed, policies that address ability-to-pay concerns include publicly provided low-rent housing, subsidies for private construction of housing for low-income households, and programs that promote geographic, and thus economic, mobility (Quigley 2000; Chetty et al. 2014). In the United States, certain aspects of the social safety net, such as health insurance and education, are tied to where one lives, so the challenges of housing affordability interact with how the social safety net affects household well-being. More fundamentally, shelter is a necessary ingredient for human survival, so at a time when catastrophic weather events are likely to increase in frequency, indiscriminately threaten the existing housing stock, and haphazardly destroy wealth, policymakers may wish to provide social insurance against these shocks.

Unfortunately for policy, limited research and evidence exists on the relative importance of various explanations for why affordability presents such a challenge. For example, a vast literature points to the role of regulations in pushing up housing costs, but little research disentangles this explanation from the contribution of economic fundamentals or financial market frictions (see Quigley and Rosenthal [2005] for a summary). Moreover, because regulations are hard to quantify and take many forms, it is difficult to know more systematically the areas where regulations have greater bite. As another example, consider the research that argues that stagnating incomes have strained affordability (Gabriel and Painter 2017). Absent additional research and evidence on the relative contributions of regulations and stagnating incomes to worsening affordability, policymakers may have limited guidance on where to direct their efforts and where they may have the greatest impact. They may also face barriers to knowing whether the challenges are national or local in scope.

Also, researchers could do more to develop the evidence base on the effectiveness and efficiency of existing policies aimed at affordability. Additional research along these lines would help direct public resources to their most productive uses. For example, knowing whether housing policies that address ability-to-pay concerns are an efficient way to reduce income inequality, or if other redistributive policies_-such as cash transfers-can achieve the same goal at a lower cost to society, would help inform the discussion on how to achieve a particular policy goal at the lowest cost to the taxpayer. 


\section{NeED FOR MEASUREMENT}

Most obviously, policymakers need a measure of affordability in order to observe the outcome they are aiming to affect. However, there is no sufficient statistic for housing affordability; instead, existing measures cover ratios of debt to house prices or to income, comparisons of costs or debt service burdens to income, the ratio of house prices to income, and various "ability to repay" standards for homebuyers with mortgages (see Ben-Shahar, Gabriel, and Golan [2017] for a summary). With no clear measure of housing affordability, policymakers may be unable to develop a systematic understanding of the challenges or may rely too heavily on anecdotes, rather than evidence, to shape their perspectives.

Moreover, existing measures may fall short of capturing whether housing is affordable for at least two reasons. First, owing to the frequent use of aggregated or market-level data, such estimates will miss distributional considerations and the extent to which affordability challenges are widespread across households. Second, in microdata, a household's housing costs are endogenous to its preferences and affordability constraints, so they may not exogenously capture whether broader factors in the housing market are holding back affordability. Both of these measurement issues may lead to under- or overstatements of whether housing is affordable.

These measurement issues also mean that it is difficult to know, based on the available data and usual measures, whether affordability is worsening or improving over time. Changes in trends can often provide important signals to policymakers about the need for, and urgency of, policy interventions. But, generally, noisy signals make it more time-consuming to understand the trends and to deliberate the appropriate actions. In the specific case of policies targeted to housing affordability, they also make it difficult to discern whether national or local policies are warranted.

\section{Misalignment of Existing Policy Tools}

A range of policies already take aim at housing affordability, both directly and indirectly. These include tax policies such as the mortgage interest deduction and the low-income housing tax credit (LIHTC), programs like housing vouchers and Federal Housing Administration (FHA) mortgage insurance, and regulations such as inclusionary zoning, rent control or rent stabilization programs, and the "qualified mortgage" (QM) rule. While research evaluating these policies is far from conclusive, a large literature suggests that unintended consequences may lessen and sometimes even undermine the affordability objectives they seek to promote.

One such unintended consequence is when house prices or rents rise as a result of a policy. Such an increase can happen when the subsidization of an aspect of homeownership boosts housing demand and the additional demand puts upward pressure on prices (in part because of some upward slope to the housing supply curve). For example, much research argues that the mortgage interest deduction raises equilibrium home prices to some extent (Capozza et al. 1996). Research on recent decreases in FHA mortgage insurance premiums-decreases that lower the cost of borrowing-suggests a pass-through effect to higher house prices (Oliner et al. 2018). In the rental market, research finds that housing voucher subsidies can increase rents for low-income households, particularly in housing markets with tight supply 
(Susin 2002). Research also finds that rental regulations are priced into rents and that landlords screen tenants more heavily to ration the supply of rental housing (Turner and Malpezzi 2003; Ambrose and Diop 2017).

Another unintended consequence occurs when the beneficiaries of policies are skewed relative to the intent. Although one rationale for the mortgage interest deduction is to increase homeownership, much of the benefit accrues to higher-income households, who would be homeowners anyway, and less goes to low- and middle-income households on the margin (Glaeser and Shapiro 2003). Similarly, research finds that the benefits of rent-control policies, which aim to limit housing outlays, are misallocated across demographic groups (Glaeser and Luttmer 2003).

In some instances, policies may induce behavioral responses that, to some extent, unwind affordability objectives. For example, Jacob and Ludwig (2012) find that housing vouchers reduce labor force participation and earnings while increasing cash welfare assistance. A large literature evaluating the LIHTC's housing production subsidies estimates that the program displaces the construction of rental housing and thus has limited supply-side effects (Baum-Snow and Marion 2007; Eriksen and Rosenthal 2010).

On a final note, it is important to recognize that analyzing the policies discussed here in terms of their affordability implications is not an exhaustive evaluation of their merits. Indeed, research and evidence suggest that, in some cases, the policies meet other important objectives, such as increased economic mobility, reductions in crime, improved housing quality, and greater economic integration within neighborhoods. Hence, addressing affordability challenges will typically interact with other aspects of economic well-being, and policymakers would benefit from research that promotes an understanding of these trade-offs.

\section{Consideration of the Political Environment}

It is no secret that the political environment generally poses challenges to promulgating evidence-based policies. In the case of housing affordability, two observations are worth noting. First, additional research on the mechanisms that constrain housing affordability would make a significant contribution to policy development. Many potential new policies could be undertaken but may not be because there is considerable uncertainty as to whether the policy goals could be achieved or whether the gains would justify the political costs of taking action. For example, some have argued that a national regulatory census would be a useful first step for systematically improving land-use regulations' effect on affordability (see Quigley and Rosenthal [2005]). Research that helps to determine whether the benefits of undertaking this effort would outweigh the political costs of diverting resources from other public programs (particularly those addressing affordability) would help guide policymakers' decision making.

Second, absent research and evidence, policymakers have an even stronger tendency to adhere to the views of self-interested stakeholders. For example, because there is little systematic measurement of land-use regulations, their regional variation, and how they have evolved over time, NIMBY-ism tends to have an outsize voice in housing supply debates. Another example concerns the subsidies for homeownership that the government-sponsored enterprises (GSEs) are perceived to provide to low-income and low-wealth households. Little 
research directly addresses this question and, instead, perceptions of large subsidies support advocacy either for preserving the GSE conservatorship or for recapitalizing and privatizing the GSEs. More research on both of these issues-and others-would help provide a counterweight to specious arguments about the drivers of affordability.

\section{Achieving Housing Affordability Objectives THROUgh Housing FinANCE REFORM}

It is not unreasonable for policymakers to want to achieve multiple objectives using one policy lever, and it may be natural to ask whether and by how much comprehensive reform of the secondary-market GSEs Fannie Mae and Freddie Mac would improve today's challenges with housing affordability. While additional research would help unpack the relationship between secondary markets and the burden of housing costs, a number of considerations suggest that the effects are unlikely to be direct or immediate. For one, comprehensive housing finance reform would likely be phased in under a protracted timeline once legislation is enacted. Moreover, reforming financial institutions that fund mortgages would likely have limited effects on the cost of borrowing as long as mortgage rate spreads relative to long-term Treasury securities reflect the underlying economic risks of lending, which are, on balance, likely to remain little changed. And even if housing finance reform were to lower the cost of mortgage credit, perhaps through additional subsidies, housing affordability could worsen absent additional housing supply, as discussed earlier (see Section 3).

Other aspects of reform proposals also point to a limited effect on affordability. For example, some reform proposals aim to address housing affordability concerns through a structure akin to that of a "trust fund," whereby money is allocated to pay for affordability programs and community development assistance. However, given the existing issues with measurement and the misalignment between policies and affordability objectives, it is unclear whether the funds would be spent in ways that maximize their efficacy. Additional research into how affordability trust funds could best be allocated would help reduce uncertainty in distributing funds during the policymaking process. Also, setting risk-based pricing as a key goal of GSE reform, as many proposals do, would limit the extent to which high-risk households could obtain cheap credit. Although some proposals allow for the cross-subsidization of higher-risk households, important questions remain as to how much cheaper credit could be with these cross-subsidies. Research that promotes an understanding of high-risk households and their ability to pay for credit would help policymakers judge how they should view the trade-off between risk-based pricing and the affordability of mortgage credit.

Acknowledgments: The author thanks Brent Ambrose for helpful comments and insights. 


\section{REFERENCES}

Ambrose, B., and M. Diop. 2017. "Information Asymmetry, Regulations, and Equilibrium Outcomes: Theory and Evidence from the Housing Rental Market.” Working paper.

Baum-Snow, N., and J. Marion. 2009. "The Effects of Low Income Housing Tax Credit Developments on Neighborhoods.” Journal of Public Economics 93, no. 5-6: 654-66.

Ben-Shahar, D., S. Gabriel, and R. Golan. 2017. "Measures of Affordability and Inequality." Presentation for the American Enterprise Institute Conference on Housing Affordability.

Capozza, D., R. Green, and P. Hendershott. 1996. “Taxes, Home Mortgage Borrowing, and Residential Land Prices.” In H. Aaron and W. G. Gale, eds., Fundamental Tax Reform. Washington, D.C.: The Brookings Institution.

Chetty, R., N. Hendren, P. Kline, and E. Saez. 2014. "Where is the Land of Opportunity? The Geography of Intergenerational Mobility in the United States.” NBER Working Paper no. 19843, June.

Eriksen, M. D., and S. S. Rosenthal. 2010. "Crowd Out Effects of Place-Based Subsidized Rental Housing: New Evidence from the LIHTC Program.” Journal of Public Economics 94, no. 11-12: 953-66.

Gabriel, S., and G. Painter. 2017. "Why Affordability Matters." UCLA Affordable Housing Policy Brief.

Glaeser, E., and E. F. P. Luttmer. 2003. “The Misallocation of Housing under Rent Control.” American Economic Review 93, no. 4 (September): 1027-46.

Glaeser, E., and J. Shapiro. 2003. "The Benefits of the Home Mortgage Interest Deduction.”

In J. M. Poterba, ed., Tax Policy and the Economy, Volume 17. Cambridge: NBER/MIT Press.

Hsieh, C.-T., and E. Moretti. 2017. "Housing Constraints and Spatial Misallocation.” NBER Working Paper no. 21154.

Jacob, B., and J. Ludwig. 2012. "The Effects of Housing Assistance on Labor Supply: Evidence from a Voucher Lottery." American Economic Review 12, no. 1: 272-304.

Joint Center for Housing Studies. 2018. "State of Our Nation's Housing." Harvard University.

Oliner, S. D., T. Peter, E. J. Pinto, and M. A. Davis. 2018. “The Impact of Federal Housing Policy on Housing Demand and Homeownership: Evidence from a Quasi-Experiment." American Enterprise Institute, AEI Economics Working Paper Series, no. 2018-01.

Quigley, J. 2000. “A Decent Home: Housing Policy in Perspective.” Brookings-Wharton Papers on Urban AfFairs 2000: 53-88. 


\section{REFERENCES (CONTINUED)}

Quigley, J., and S. Raphael. 2004. "Is Housing Unaffordable? Why Isn't It More Affordable?" Journal of Economic Perspectives 18, no. 1 (Winter): 191-214.

Quigley, J., and L. Rosenthal. 2005. "The Effects of Land-Use Regulation on the Price of Housing: What Do We Know? What Can We Learn?" Cityscape: A Journal of Policy Development AND RESEARCH 8, no. 2: 69-137.

Stiglitz, J., and A. Weiss. 1981. "Credit Rationing in Markets with Imperfect Information." American ECONOMic Review 71, no. 3: 393-410.

Susin, S. 2002. "Rent Vouchers and the Price of Low-Income Housing." Journal of Public

ECONOMICs 83, no. 1: 109-52.

Turner, B., and S. Malpezzi. 2003. "A Review of Empirical Evidence on the Costs and

Benefits of Rent Control." Swedish Economic Policy Review 10: 11-56.

The Economic Policy Review is published by the Research and Statistics Group of the Federal Reserve Bank of New York. The views expressed are those of the individual authors and do not necessarily reflect the position of the Federal Reserve Bank of New York or the Federal Reserve System. Economic Policy Review articles may be reproduced for educational or training purposes, provided they are reprinted in full; include credit to the author(s), the publication, and the Bank; and include the publication's disclaimer.

(C) 2018 The Federal Reserve Bank of New York 